\title{
Hagamos murallas más bajas
}

\author{
Let us lower the walls \\ Osvaldo Melgarejo ${ }^{1}$ \\ ${ }^{1}$ Universidad Nacional de Asunción, Facultad de Ciencias Médicas, Cátedra de Psiquiatría, San Lorenzo, Paraguay.
}

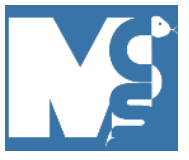

Recibido: 19/11/2020

Revisado: 19/11/2020

Aceptado: 19/11/2020

\section{Autor correspondiente}

Osvaldo Melgarejo

Universidad Nacional de Asunción

San Lorenzo - Paraguay

osvi melgarejo@hotmail.com

\section{Conflictos de interés}

El autor declara no poseer conflictos de interés.

\section{Fuente de financiación}

El autor no recibió apoyo financiero para la investigación, autoría y/o publicación de este artículo.

Este artículo es publicado bajo una licencia de Creative Commons Reconocimiento 4.0 Internacional.

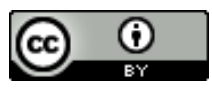

Cada vez que nuestra mente entra en contacto con ideas que se oponen a las ideas a las que estamos acostumbrados, entra en conflicto. El conflicto, lo resuelve a través atajos mentales que se adquieren a través de la cultura, de lo aprendido y de lo vivido. Pero, ¿Qué sucede cuando el conflicto está en la cultura, en lo aprendido o en lo vivido? O ¿Qué sucede cuando el sentir hacia personas del mismo sexo es el conflicto?

Ocultar de las personas lo que uno siente como reprochable evita el castigo social y la discriminación. Castigamos transgresiones morales de otros para mejorar nuestra reputación social (1) y, hoy día, las redes sociales amplifican y magnifican el castigo. A la hora de señalar esta indignación moral, las personas lo hacen más bien para cuidar su reputación que buscando comprender, tolerar y aceptar. Entonces, si trasgresiones morales son castigadas y sometidas al proceso de humillación, es entendible que la orientación sexual se oculte.

Se ha explorado la relación entre emociones y prejuicio, en la que ciertas creencias ampliamente aceptadas, pero no necesariamente acertadas, pueden desencadenar estados afectivos en ciertas personas (2) y reducir el umbral para el prejuicio, esto puede ir más allá cuando la homonegatividad puede ser evocada solamente con la imaginación (3). Solo hace falta tener una conversación sobre un tema, en un contexto con ideas opuestas a las de uno para que estas se repriman y que esto se repita en otros contextos hasta el punto en que sea uno mismo el que rechace estas ideas y genere un conflicto intrapsíquico (4).

En esta edición de la Revista "Medicina Clínica y Social", se presenta un estudio realizado en la Facultad de Ciencias Médicas de Universidad Nacional de Asunción (5), que señala que el encubrimiento de la orientación sexual de las personas no se da solamente en ambientes fuera del académico, si no que en la misma unidad académica formadora en la que "salir del closet" puede ser un reto aun mayor, si el hecho repercute sobre su futuro.

Utilicemos una muralla como analogía al punto sobre si expresar o no la orientación sexual. Si consideramos que la cultura, el entorno académico o laboral, la familia y las redes primarias de apoyo van a marcar la altura de la muralla, ¿qué tan alta es la muralla en la que usted vive, trabaja o estudia? ¿Qué podemos hacer nosotros como sociedad? y ¿Qué pueden hacer las instituciones para hacerlas más bajas? 


\section{REFERENCIAS}

1. Jordan J, Kteily N. People punish moral transgressions for reputational gain, even when they personally question whether punishment is merited. Version: 3. PsyArXiv [Preprint]. [posted 2020 Mar 21; revised 2020 Oct 21; cited 2020 Nov 11]: [39 p.]. Available from: https://doi.org/10.31234/osf.io/97nhi

2. Kiss MJ, Morrison MA, Morrison TG. A Meta-Analytic Review of the Association Between Disgust and Prejudice Toward Gay Men. J Homosex. 2020;67(5):674-696. https://doi.org/10.1080/00918369.2018.1553349

3. Bishop C. Emotional reactions of heterosexual men to gay imagery. J Homosex. 2015;62(1):51-66. https://doi.org/10.1080/00918369.2014.957125

4. Frost DM, Meyer IH. Internalized Homophobia and Relationship Quality among Lesbians, Gay Men, and Bisexuals. J Couns Psychol. 2009;56(1):97-109. https://doi-org/10.1037/a0012844

5. Cardozo-Torres H, Leon-Stimson R, Ullón-Godoy M, Mancuello-Gómez J, Palma-Cegla C, Pipirig T, et al. ¿Dentro o fuera del clóset? Apertura y/o encubrimiento de la orientación sexual de estudiantes de Medicina de la Universidad Nacional de Asunción. Med. Clín. soc. 2021;5(1):3-10. https://doi.org/10.52379/mcs.v5i1.163 


\title{
Let us lower the walls
}

\author{
Hagamos murallas más bajas \\ Osvaldo Melgarejo ${ }^{1}$ \\ ${ }^{1}$ Universidad Nacional de Asunción, Facultad de Ciencias Médicas, Cátedra de Psiquiatría, San Lorenzo, Paraguay.
}

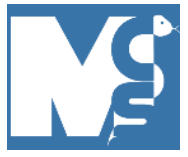

Received: 19/11/2020

Revised: $19 / 11 / 2020$

Accepted: 19/11/2020

\section{Corresponding author}

Osvaldo Melgarejo

National University of Asunción

San Lorenzo - Paraguay

osvi melgarejo@hotmail.com

\section{Conflicts of interests}

The author declares that there is no conflict of interest.

\section{Funding}

The author received no financial support for the research, authorship, and/or publication of this article.

This article is published under Creative Commons Attribution 4.0 International License.

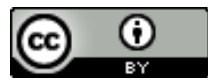

Every time our mind encounters ideas that are opposed to those we are used to, conflicts arise. These conflicts are resolved through mental shortcuts that are acquired through culture, through what we have learned and what we have lived. But what happens when our own identity conflicts with the culture, with what we have learned and lived? What happens when attraction towards people of the same sex is the conflict?

Hiding from other people something one considers to be reprehensible can spare an individual from social punishment and discrimination. We punish moral transgressions of others to improve our social reputation (1) and, today, social networks amplify and magnify that punishment. When it comes to pointing out this moral outrage, people do so more to guard their reputation than to understand, tolerate, and accept. So, if moral transgressions are punished and the transgressors are punished, it is understandable why non-traditional sexual orientations are hidden.

The relationship between emotions and prejudice has been explored, in which certain widely accepted beliefs, but not necessarily correct, can trigger affective states in certain people (2) and reduce the threshold for prejudice, this can go further when homonegativity can only be evoked with imagination (3). A simple conversation about a topic, in a context with ideas that are opposite to one's own, can lead to these ideas being repressed, and for this to be reproduced in other contexts to the point where one rejects their original ideas, which can lead to intrapsychic conflicts (4).

This edition of the Journal "Medicina Clínica y Social" presents a study carried out at the Faculty of Medical Sciences of the National University of Asunción (5), which shows that the concealment of people's sexual orientation occurs not only outside the academic environments, but also in the same academic training unit, in which "coming out of the closet" can be even more challenging when the individual's career is at stake.

Let us use a wall as an analogy for the decision to express or to conceal one's sexual orientation. If we consider that culture, academic or work environment, family and primary support networks will mark the height of the wall, how high is the wall on which you live, work or study? What can we do as a society, and what can the institutions do to lower the wall? 


\section{REFERENCIAS}

1. Jordan J, Kteily N. People punish moral transgressions for reputational gain, even when they personally question whether punishment is merited. Version: 3. PsyArXiv [Preprint]. [posted 2020 Mar 21; revised 2020 Oct 21; cited 2020 Nov 11]: [39 p.]. Available from: https://doi.org/10.31234/osf.io/97nhi

2. Kiss MJ, Morrison MA, Morrison TG. A Meta-Analytic Review of the Association Between Disgust and Prejudice Toward Gay Men. J Homosex. 2020;67(5):674-696. https://doi.org/10.1080/00918369.2018.1553349

3. Bishop C. Emotional reactions of heterosexual men to gay imagery. J Homosex. 2015;62(1):51-66. https://doi.org/10.1080/00918369.2014.957125

4. Frost DM, Meyer IH. Internalized Homophobia and Relationship Quality among Lesbians, Gay Men, and Bisexuals. J Couns Psychol. 2009;56(1):97-109. https://doi-org/10.1037/a0012844

5. Cardozo-Torres H, Leon-Stimson R, Ullón-Godoy M, Mancuello-Gómez J, Palma-Cegla C, Pipirig T, et al. ¿Dentro o fuera del clóset? Apertura y/o encubrimiento de la orientación sexual de estudiantes de Medicina de la Universidad Nacional de Asunción. Medicina Clínica y Social. 2021;5(1):3-10. 